\title{
Phytosanitary monitoring of Lilium rhodopaeum Delip. in Bulgaria
}

\author{
Sergey Bistrichanov ${ }^{1}$, Ivanka Ivanova ${ }^{2}$, Andrei Kaninski ${ }^{2}$, E .Kadhum ${ }^{3}$ \\ ${ }^{1}$ University of Forestry, Faculty of Agronomy \\ ${ }^{2}$ Institute of Ornamental Plants - Sofia, Bulgaria \\ ${ }^{3}$ Ministry of Agriculture and Food - Bulgaria
}

Rec. 15 May, Accept. 20 July 2010

\begin{abstract}
During previous four years (2005-2008), the natural enemies (pests and pathogens) of Lilium rhodopaeum Delip. in Rodopa Mountain was studied. The phytosanitary status of its habitats was assessed and determined. The investigated populations were stable and showed slow-steady increasing during the years of monitoring. In general, phytosanitary status was good enough except for Tzigansko gradishte where more attention was considered to this rare species and some measures were applied to preserve it. All investigated populations of Lilium rhodopaeum Delip. suffered from the same problems, the plants were attacked by pests (grasshoppers and beetles) and pathogens (grey mold).
\end{abstract}

Key words: Lilium rhodopaeum; Monitoring; Phytosanitary status; Pests; Pathogens

\section{Introduction}

Bulgaria belongs to rare countries in Europe with huge floristic diversity and almost $12 \%$ of plants species are endemics (Biological Diversity Act, 2002, Bulgraria, 1984). The taxon Lilium rhodopaeum Delip. was first reported by Delipavlov (Delipavlov, 1951), he found this flower in Rodopa Mountain. At the present time, the plants are known only in few habitats in Bulgaria and Southeast Greece.

Lilium rhodopaeum Delip is a Balkan endemite, listed in Bern convention and has a status rare (Bulgraria, 1984). The taxon have been investigated by many researchers (Delipavlov, 1951; Nencheva et al., 1996; Popova 1970; Protich, 1987; Vitanova et al., 1995, 1996; Vitanova and Kaninski, 2001), but data concerning its phytosanitary status couldn't obtained in the literature resources. During previous four years (2005-2008), the natural enemies (pest and pathogens) of Lilium rhodopaeum Delip were observed, therefore, our goal was to determine them and to assess phytosanitary status of investigated populations.

\section{Material and Methods}

During the previous four years (2005 - 2008), several expeditions were made in Rodopa Mountain - near villages Sivino (N 41 ${ }^{\circ} 40^{\prime}$, E $24^{\circ} 43^{\prime}$ and $1325 \mathrm{~m}$ above sea level), Progled (N $41^{\circ} 26^{\prime}$, E $24^{\circ} 40^{\prime}$ and $1179 \mathrm{~m}$ above sea level) and Tzigansko gradishte area (N $41^{\circ} 21^{\prime}$, E $24^{\circ} 47^{\prime}$ and $1538 \mathrm{~m}$ above sea level) near Greece border. At the first two years, data were obtained from literature resources and through application of questionnaires among local citizens. In addition, these places were visited twice (during phases of blossom and maturity). Natural enemies (pests and pathogens) were checked, noticed and damages on the plants were investigated.

\footnotetext{
* Corresponding author: Dr. Sergey Bistrichanov $\bowtie$ Faculty of Agronomy, University of Forestry, Bulgaria
} 
To determine natural effect of enemies, plant parts with visible symptoms were collected and subject for lab investigations using wet camera, microscopic observations for pathogens and pests. Populations were estimated by following criteria: increase or decrease as well as the amount of plants is constant to check where they are stable or not. The phytosanitary status was assessed using three scale levels: bad - over $50 \%$ of plants are dead or destroyed, satisfactory - from 10 till 50\% and good -less $10 \%$ of plants with some damages by enemies.

\section{Results and Discussion}

Lilium rhodopaeum Delip is spread in some areas of the Rodopa Mountain. The investigated habitats are determined and each one has own specificity despite the non greater distance between them, consequently, they were unique and populations were discussed one by one.

\section{Village Sivino (locus classicus)}

The territory is protected by Bulgarian law and population is numerated (over one thousand) and stable. The most common problems are caused by pests (Table 1). Damages were mainly on reproductive and generative plant parts. The presence of locusts and phyllophagous was identified. Insects were from orders Tettigonidae and Chrysomelidae. They attack green plant parts, flowers and seed boxes. They nibbled stem and leaves, and sometimes the flower dyed. From locusts, Tettigonia viridissima L. were mainly checked and sometimes Decticus verrucivorus $\mathrm{L}$ were also investigated.

\begin{tabular}{|c|c|c|c|}
\hline \multirow{2}{*}{$\begin{array}{c}\text { Habitats } \\
\text { status/average }\end{array}$} & \multicolumn{2}{|c|}{ Threats and damages } & \multirow[t]{2}{*}{ Phytosanitary } \\
\hline & Pests & Pathogens & \\
\hline Sivino & $\begin{array}{c}\mathrm{G}-\text { bite of leaves and stems; } \mathrm{LB}- \\
\text { nibble of flower parts }\end{array}$ & GM - on flowers & good \\
\hline Progled & $\begin{array}{c}\mathrm{G}-\text { bite of leaves and stems; } \mathrm{LB}- \\
\text { nibble of flower parts }\end{array}$ & not found & good to satisfactory \\
\hline Tzigansko gradishte & $\begin{array}{c}\mathrm{G}-\text { bite of leaves and stems; } \mathrm{LB}- \\
\text { nibble of flower parts }\end{array}$ & $\mathrm{GM}$ - on flowers & bad \\
\hline
\end{tabular}

Table (1) Lilium rhodopaeum Delip habitats in the Rodope Mountain, threats and phytosanitary status 2005-2007

Our opinion was that major threats were damages of the flower parts (florets and flower buds). In the nature, Lilium rhodopaeum multiply by seeds and destroying of flowers caused serious problems to population stability for a long term period. At Sivino leaf beetle from genus Lilioceris (Lilioceris lilii Scopoli.) were recorded. On separate florets, we observed decay, which identified after laboratory inspections as gray mold. During the studied years, population status was stable and damages vary from 10 to $30 \%$. Phytosanytary status assessment was with level good.

\section{Village Progled}

The territory is protected by Bulgarian law and population is not numerated (between 200 and 500 ) but stable and slow steady increasing during the years of monitoring were detected. The problems were similar with those in Sivino (Table 1). We identified locust Tettigonia viridissima $\mathrm{L}$. which bit off handle of flower and plants loose them (about 50\%). On separated plants, we registered Lilioceris lilii Scopoli. Phytosanytary status varies from satisfactory to good level. 


\section{Area Tzigansko gradishte}

The area is located through Bulgarian and Greece border. In the past, this zone was strictly guarded and prohibited even though for researchers. Lilium rhodopaeum is spread in narrow strip along the border line. The population was diffused but numerated. The situation was worst there. Grasshoppers were Tettigonia viridissima L., Decticus verrucivorus L. and Isophya tenuicera Ramme. A damage of locusts wasn't so serious but the main problem happened from leaf beetles from genus Lilioceris. Nearly $80 \%$ of plant buttons in the population was damaged from larvae and adults phyllophagus and they found almost on any plant (Table1). Two species Lilioceris lilii Scopoli; Lilioceris merdigera $\mathrm{L}$ were found. As in Sivino, Tzigansko gradishte showed similar symptoms on the flowers, they belonged to gray mold and genus Botrytis.

In general, all the obtained data allowed some of the following statements: Phytosanytary status assessment of the population in area Tzigansko gradishte was categorized as bad. Investigated Lilium rhodopaeum Delip. populations were stable and slow steady increasing was recorded during the years of monitoring. For all investigated habitats phytosanitary status is good (except Tzigansko gradishte) but we have to pay more attention to this rare species and keep on aye (by annual monitoring), consider and apply some measures to preserve it. All investigated populations of Lilium rhodopaeum Delip. have similar problems. The plants were attacked from pests (grasshoppers -family Tettigonia and phyllophagus beetles from g. Lylioceris) and pathogens (grey mold).

\section{References}

Biological Diversity Act. 2002. Bulgaria State Gazette, 77.

Bulgraria R. 1984. Plants, BAS, Sofia

Delipavlov D. 1951. Lilium rhodopaeum Delip. Scientific papers VSI "V. Kolarov" Plovdiv, v. I, 219-224.

Nencheva D., Kaninski A., Vitanova G. and Protich N. 1996. Micropropagation of two protected wild species of Lilium. In: II International symposium Salaspils, Latvia, April 16-18,’Breeding, Propagation in vitro and disease resistance of Horticultural Plants, Thesis (pp. 29-32).

Popova M. 1970. Some remarks on the lilies of the Balkans, The Lily year Book 1970 (66-70.)

Protich N. 1987: Studies on six types of bulbs from the flora of Bulgaria with a view to their suitability for use in horticulture, Plant Science, XXIV, 6, 59-63.

Vitanova G., Protich N., Kaninski A. and Nencheva D. 1995. Preservation of protected species Lilium rhodopaeum Delip., Scientific papers. VSI " $V$. Kolarov" Plovdiv, v. XL, 3, 121-124.

Vitanova G., Protich N., Nencheva D. and Kaninski A. 1996. Contributing to the assessment and conservation of genplasm from protected species Lilium rhodopaeum Delip. and Lilium jankae Kern. for breeding. II Balkan scientific conference of investigation, preservation and use of forestry resources. VLTI - Sofia, 3 - 5 June, Proceedings (pp. 345-349).

Vitanova G. and Kaninski A. 2001. Some specifics in cultivation of species of G. lilium. Agrar University - Plovdiv, Scientific papers, vol. XLVI, 4, 167-172. 